\title{
PRÁŠKOVÉ ČÁSTICE PRO PLICNÍ PODÁNÍ
}

\section{Jakub Karas, DaVid VetchÝ a JAN GAJDZIOK}

Ústav farmaceutické technologie, Farmaceutická fakulta, Masarykova Univerzita, Palackého tř. 1946/1, 61200 Brno

gajdziokj@pharm.muni.cz

Došlo 22.3.21, přijato 21.9.21.

Klíčová slova: inhalace suchých prášků, velké porézní částice, metody př́ipravy částic, sprejové sušení, depozice v plicích, umělé plíce

- https://doi.org/10.54779/chl20220028

\section{Obsah}

1. Úvod

2. Plicní depozice suchých částic po inhalačním podání

3. Hodnocení vlastností částic pro plicní aplikaci

3.1. Tokové vlastnosti, hustota, pórovitost

3.2. Fyzická velikost a morfologie

3.3. Aerodynamický průměr

3.4. Depozice částic v modelu plic

4. Metody př́pravy suchých částic pro plicní aplikaci

4.1. Krystalizační techniky

4.2. Mikronizace a mletí

4.3. Sprejové sušení

4.4. Sprejová lyofilizace

4.5. Kombinované techniky (emulgace, enkapsulace)

5. Závěr

\section{1. Úvod}

Aerosoly jsou v klinické praxi součástí léčby široké škály onemocnění. Mohou být podávány na kůži i sliznice, dominantně pak inhalačně k léčbě respiračních onemocnění (infekce DCD, CHOPN, tuberkulóza, nádorová onemocnění, cystická fibróza, atd.), ale i k docílení systémového efektu (např. u DM II, genové terapii, atd.) ${ }^{1,2}$. Aplikace inhalačních aerosolů představuje neinvazivní způsob podání nesoucí řadu výhod: omezení „first-pass efektu“, degradace léčiva $\mathrm{v}$ trávicím traktu, bohaté krevní zásobení plicní tkáně a její velká absorpční plocha ${ }^{3}$. Inhalační léky ve farmaceutické terminologii dělíme podle skupenství aplikovaných částic na tzv. tekuté inhalační přípravky (páry, tekutiny pro rozprašování, dávkované tlakové př́í- pravky) a inhalační prášky. Prášky pro inhalaci jsou do plic dopravovány pomocí práškových inhalátorů (DPI), které jsou spolu s kapalnými dávkovanými inhalátory (MDI) pro své výhody (stabilita, přesnost dávkování, malé rozměry) nejpouživanějšími typy ${ }^{4}$. Cílem příspěvku je poskytnout základní přehled o moderním trendu v oblasti inhalačních aerosolů, který představují velké porézní částice. Problematika je diskutována jak z pohledu vlastností, které musí tyto formulace splňovat, tak i metod farmaceutické technologie používaných pro prípravu vhodných mikročástic $\mathrm{s}$ uvedením konkrétních př́kladů $\mathrm{z}$ oblasti výzkumu i klinického použití.

\section{Plicní depozice suchých částic po inhalačním podání}

Plíce jsou silně prokrvený orgán o absorpční ploše asi $100 \mathrm{~m}^{2}$. Tenká buněčná bariéra umožnuje téměř okamžitý prostup i velkých molekul léčiv. Výhodou je i nízká enzymatická aktivita epitelu. Podání farmaka plicní cestou představuje neinvazivní způsob aplikace $\mathrm{v}$ př́ípadech, kdy je nevhodná injekční či perorální cesta. Příliš velké či malé částice nemohou dosáhnout terapeutického účinku v distálních oblastech plic. Malé částice jsou vydechovány nebo eliminovány buňkami imunitního systému. Velké částice ulpívají v horních cestách dýchacích nebo již v dutině ústní. Velikost částic farmaceutických aerosolů se proto musí pohybovat v tzv. respirabilním rozmezí $(1-3 \mu \mathrm{m})$ (cit. ${ }^{2}$ ). Nevýhodou těchto částic je rychlá eliminace přirozenými mechanismy (imunitní systém, mukociliární transport). To vede $\mathrm{k}$ nutnosti častého dávkování. Moderním formulačním trendem pro př́pravu částic pro hlubokou plicní depozici jsou tzv. velké porézní částice (LPP) o fyzickém průměru $>5 \mu \mathrm{m}$ a hustotě $\leq 0,4 \mathrm{~g} \mathrm{~cm}^{-3}$ (cit. ${ }^{1}$ ). Použitím těchto formulací lze docílit prodlouženého uvolňování léčiva ${ }^{5}$. Tyto částice musí splňovat řadu parametrů zásadních pro jejich očekávanou depozici $\mathrm{v}$ dýchacím traktu. Moderní farmaceutické technologie umožňují jejich přípravu různými technikami, jejichž př́klady jsou uvedeny $\mathrm{v}$ dalších kapitolách ${ }^{1,5}$

Kromě parametrů samotných částic (tvar, velikost, hustota, složení), resp. vlastností výsledného aerosolu (fyzika aerosolů) ovlivňuje depozici také anatomie dýchacích cest a způsob dýchání. Při inhalaci působí na částice několik fyzikálních principů ovlivňujících jejich výsledné chování v dýchacích cestách. Dủležitým faktorem je také dispergace částic před samotnou aplikací. Pro popis depozice suchých částic $\mathrm{v}$ plicích bylo definováno několik mechanismů, u kterých hrají podstatnou roli právě jejich aerodynamické vlastnosti. Jde o principy: zachycení - částice v blízkosti stěny na ní ulpí; setrvačný mechanismus - projevuje se převážně $\mathrm{v}$ horních cestách dýchacích, kdy těžší 
částice nejsou schopny pokračovat ve směru proudění vzduchu dál do plic; sedimentace - uplatňuje se při nižších rychlostech v bronchiolech a jejich větveních, podle míry proudění dochází $\mathrm{k}$ usazování lehčích částic; difuze - popisovaná $\mathrm{v}$ celých plicích vlivem a mírou turbulentního proudění; elektrostatická precipitace - pokud se látka nesoucí náboj přiblíží ke stěně, je vytvořeno zrcadlové napětí a částice tak ke stěně přilne ${ }^{6}$. Heyder a spol. na základě in vivo studie definovali tři cesty transportu a mechanismy usazování částic na povrchu dýchacích cest. U termodynamické cesty (usazování difuzními mechanismy) hraje roli pouze průměr částice, ne její hustota. Přechodová cesta/mechanismus depozice je ovlivněn hlavně délkou a hloubkou nádechu. Uplatňuje se difuze, setrvačnost a gravitace. Třetí aerodynamický mechanismus je dle velikosti deponovaných částic dělen na další tři stupně. Vliv na konečnou depozici má průtok vzduchu, doba nádechu, hustota a velikost částic. Depozice je považována za účinnou, pokud je v zamýšleném místě prrítomna polovina aerosolu z celkového množství aerosolu deponovaného v plicích ${ }^{6-9}$

\section{Hodnocení vlastností částic pro plicní aplikaci}

Vlastnosti částic suchých prášků pro inhalační podání (velikost, tvar, povrch, pórovitost, hustota, aerodynamický průměr, povrchový náboj, dispergovatelnost resp. aerosolizovatelnost) ovlivňují všechny aspekty související s jejich doručením do dýchacích cest. U finálních přípravků se navíc testuje stejnoměrnost podané dávky a dávka jemných částic (aerodynamické stanovení jemných částic) ${ }^{10}$.

\subsection{Tokové vlastnosti, hustota, pórovitost}

Jsou nejčastěji hodnoceny na základě měření sypné a setřesné hustoty, ze kterých je odvozen Hausnerův poměr. Sypná hustota je definována jako hustota volně nasypaného prášku do kalibrovaného odměrného válce. Setřesná hustota podává informace o tokových vlastnostech prášků a nepř́mo o silách působících mezi částicemi a jejich pórovitosti. Pórovitost částic má vliv na celkovou hustotu materiálu, ovlivňuje aerosolizovatelnost, rychlost uvolňovaní léčiva nebo například rozpouštění léčivé látky. $\mathrm{K}$ měřní pórovitosti materiálů s trojrozměrně distribuovanými póry je využíváno Brunauer-Emmett-Tellerovy metody, spočívající vabsorbci plynu na pevný povrch materiálu. Zjistěním objemu plynu je pak možno odvodit pórovitost. Pórovitost může být též odvozena ze zdánlivé (setřesné) a pravé (pyknometrické) hustoty materiálu. Avšak v tomto prrípadě nejde určit odděleně pro samotnou částici, ale jako komplexní vlastnost práškového materiálu, kde je brána $\mathrm{v}$ úvahu i mezerovitost prášku (void fraction) ${ }^{11,12}$.

\subsection{Fyzická velikost a morfologie}

Morfologie částic výrazně ovlivňuje jejich chování v dýchacích cestách. Nejčastěji je hodnocena mikroskopickými metodami. Optickou analýzou lze hodnotit plochu částic, ekvivalentní průměr, obvod částice, délku, šiřku, kruhovitost, tvarový faktor, hrubost, velikostní distribuci a řadu dalších parametrů. Pro detailní zobrazení struktury povrchu se využívá elektronová mikroskopie. Velikost částic je možné stanovit také pomocí rozptylu světla laserové difrakce. Jedná se o optickou metodu využívající rozptyl laserového paprsku v kapalném nebo plynném prostredí po dopadu na vzorek ${ }^{13-15}$.

\subsection{Aerodynamický průměr}

U prášků určených $\mathrm{k}$ plicnímu podání je pro úspěšnou depozici v dolních partiích plic klíčový tzv. aerodynamický ekvivalentní průměr vyjádřený rovnicí (1) (průměr sférické částice o hustotě $1 \mathrm{~g} \mathrm{~cm}^{-3}$, která má v gravitačním poli stejnou sedimentační rychlost jako sledovaná částice) (cit. ${ }^{5,6,16}$ ):

$$
d_{\mathrm{a}}=d_{\mathrm{geo}} \sqrt{\frac{\rho}{\rho_{\mathrm{ref}} \cdot X_{\mathrm{r}}}}
$$

kde $d_{\mathrm{a}}$ je aerodynamický ekvivalentní průměr, $d_{\text {geo }}$ geometrický průměr částice (obvykle změřený pomocí laserové difrakce, kdy jde o průměr referenční kulovité částice rozptylující světlo stejně, jako částice měřená; nebo získaný analýzou velikosti částic pomocí Andersenova kaskádového impaktoru), $X_{\mathrm{r}}$ tvarový faktor (hodnota 1 znamená kouli), $\rho$ zdánlivá hustota (u těchto formulací často hustota setřesná), $\rho_{\text {ref }}$ referenční hustota $1 \mathrm{~g} \mathrm{~cm}^{-3}$ (cit. ${ }^{5,16}$ ).

Pro sférické částice je aerodynamický ekvivalentní průměr rovný geometrickému průměru $d_{\text {geo }}$ (v tomto případě možno označit jako fyzický průměr částice) násobenému druhou odmocninou hustoty částice:

$$
d_{\mathrm{a}}=(\sqrt{\rho}) \cdot d_{\mathrm{geo}}
$$

$\mathrm{V}$ podstatě to znamená, že aerodynamický průměr $d_{\mathrm{a}}$ velké porézní částice (nízká hustota) může být menší než malá částice o vysoké hustotě ${ }^{8}$.

Střední aerodynamický průměr (MMAD) inhalovatelných částic je lékopisně určován pomocí tzv. Andersenova kaskádového impaktoru. Zařízením proudí plyn, který unáši částice, ty se pak dle svých parametrů usazují na odpovídající úrovni sít. Použitím Andersonova impaktoru lze také získat parametry celkového výdeje léčiva (mass output) z aplikátoru, parametr ,impactor mass“ (mg resp. \%) udávající hmotnost částic o velikosti menší než $10 \mu \mathrm{m}$ usazených v impaktoru. Klinicky nejvýznamnější parametr je údaj o frakci jemných částic tzv. „fine particle fraction“ (FPF) uváděný v procentuálním zastoupení respirabilních částic (fine particles). Jedná se o frakci emitovaných částic, které jsou menší než částice o velikosti kolem $3,5 \mu \mathrm{m}$, což je považováno za horní hranici dýchatelných částic $^{14,15,17}$. Z hodnot zdánlivé (setřesné) hustoty lze využitím rovnice (1) vypočítat aerodynamický průměr. Pro sférické částice je vzorec zjednodušen dle Edwardse (rovnice (2)). Dle dosavadních poznatků má největší množství částic, které dosáhnou alveolarní oblasti plic, velikost okolo $3 \mu \mathrm{m}$. Na základě rovnice (1) se průměr 
porézní částice $d_{\mathrm{p}}[\mu \mathrm{m}]$, která docílí maximální hluboké plicní depozice pro svoji nízkou hustotu $\rho<1$ stanoví dle vztahu $^{5}$ :

$$
d_{\mathrm{p}}=\frac{3}{\sqrt{\rho_{\mathrm{p}}}}
$$

kde $d_{\mathrm{p}}$ je průměr částice, $\rho_{\mathrm{p}}$ hustota částic (menší než 1$)$.

Pro neporézní částice může být použit vzorec teoretického aerodynamického průměru MMADt:

$$
\mathrm{MMADt}=\sqrt{\frac{\rho_{\mathrm{p}}}{\rho_{1}}} \cdot d_{\text {geo }}
$$

kde $d_{\text {geo }}$ je geometrický průměr částice, $\rho_{\mathrm{p}}$ hustota částice, $\rho_{1}$ referenční hustota o hodnotě $1 \mathrm{~g} \mathrm{~cm}^{-3}$ (cit. ${ }^{18}$ ).

Aerodynamické vlastnosti se dají změrit i pomocí tzv. APS. Principem této metody je měření doby průletu částice mezi dvěma lasery. Velké částice mají větší setrvačnost, větší Stokesovo číslo. Porovnáním s částicí o známých parametrech ve známém konstantním průtoku vzduchu lze dle Stokesova čísla zjistit aerodynamickou velikost ${ }^{6}$ :

$$
\mathrm{Stk}=\frac{\rho d_{\mathrm{a}}^{2} U}{18 \mu d_{0}}
$$

kde $d_{\mathrm{a}}(\mu \mathrm{m})$ je aerodynamický průměr částice, $U\left(\mathrm{~m} \mathrm{~s}^{-1}\right)$ rychlost proudění vzduchu, $\mu$ (Pa.s), viskozita vzduchu a $d_{0}(\mathrm{~cm})$ průměr segmentu ${ }^{6}$.

\subsection{Depozice částic v modelu plic}

$\mathrm{V}$ průběhu minulého století byly plíce popsány vícekrát, avšak k zhotovení realistického modelu plic došlo až s př́ichodem technologií jako CT a MRI. V České republice byl na základě kombinace Schmidtova modelu a CT plic dobrovolníků za spolupráce s Fakultní nemocnicí u svaté Anny a VUT Brno vytvořen realistický model s nosní i ústní dutinou určený $\mathrm{k}$ měření regionální depozice aerosolů. Nedokonalostí tohoto modelu je, že podává informace jen do sedmé generace větvení, neobsahuje plicní surfaktant, je poměrně obtížná simulace plicního prostředí o $100 \%$ vlhkosti, atd. Kombinací s počítačovou simulací však model dává hodnotná data o proudění a chování částic v dýchací soustavě. Model samotný (obr. 1) je složen z 21 od sebe oddělitelných segmentů. Nejužší větve (bronchioly) mají vnitřní průměr $3 \mathrm{~mm}$. Terminální bronchy čítají deset svodových výstupů. Každý plicní lalok je zastoupen párem př́íslušných svodů. Zmíněný model byl použit v několika měřeních. Farkas a spol. ve studii porovnávali počítačové simulace lokální depoziční frakce částic $\mathrm{s}$ experimentem na modelu plic za rozdílných dechových cyklü ${ }^{6,19-21}$.

\section{Metody př́ípravy suchých částic pro plicní aplikaci}

$\mathrm{S}$ moderním trendem přípravy větších částic $\mathrm{s}$ vysokou pórovitostí se kromě zdokonalování klasických metod prŕpravy mikročásticových systémů do výzkumu dostávají i některé technologie nové ${ }^{22}$.

\subsection{Krystalizační techniky}

Velikost a tvar krystalů hrají významnou roli při formulaci prášku pro plicní podání a jeho chování v dýchacích cestách. Malé krystaly mívají obvykle nevhodné tokové vlastnosti omezující jejich plnění do aplikátoru a desagregaci při aplikaci. Tvar krystalů ovlivňuje možnosti mikronizace, sypnou a setřesnou hustotu a také depozici v plicích. K požadované krystalizaci je nutné nastavení a kontrola řady procesních parametrů (rozpouštědlo/ srážedlo, obsah vody v něm; teplota; tlak; doba, za kterou se dosáhne přesyceného roztoku; intenzita míchání; $\mathrm{pH}$

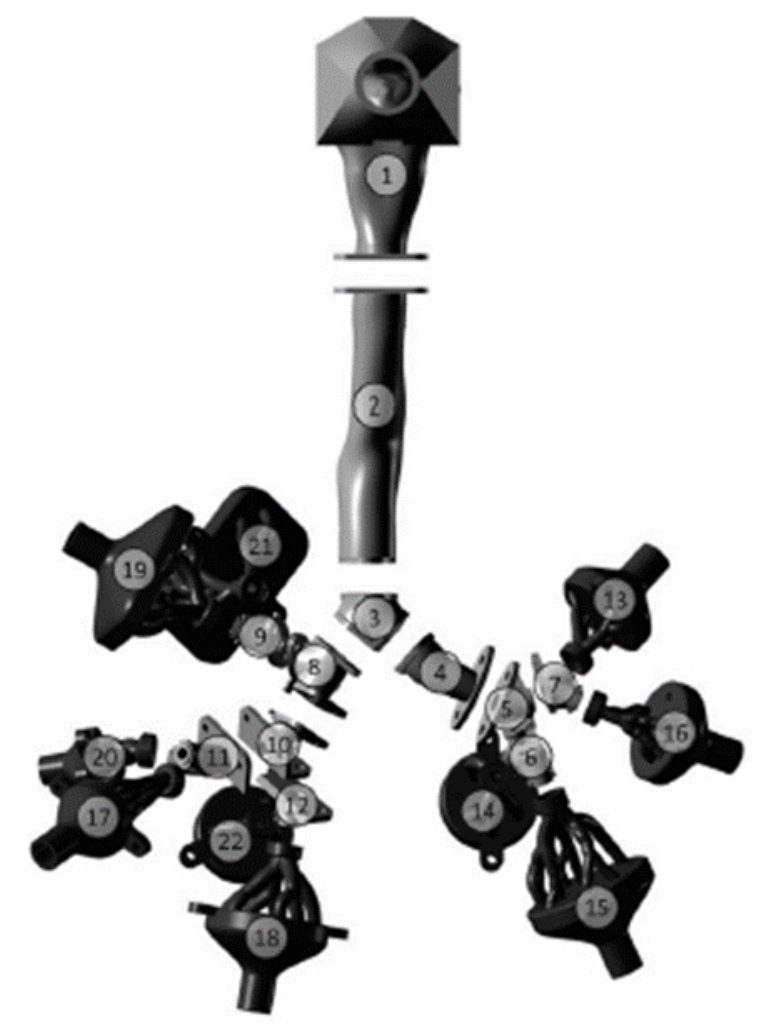

Obr. 1. Umělé plíce - segmentární model plic (konstrukce VUT Brno 2019) ${ }^{21}$ : 1- segment $\mathrm{s}$ dutinou ústní, 2 - průdušnice, 3 bifurkace, 3 - levá průduška, 5 - mezičlánek k větvení laloků, 6 větvení do pravého dolního laloku $(14,15$ - větve představující dolní levý lalok), 7 - větvení do levého horního laloku (13, 16 horní levý lalok), 8 - pravá průduška, 10 - větvení k pravému dolnímu a pravému střednímu laloku, 12 - větvení do pravého dolního laloku (22, 18 - pravý dolní lalok), 11 - větvení do pravého středního laloku (17, 20 - pravý střední lalok), 9 - větvení do pravého horního laloku (19, 21 - pravý horní lalok) 
roztoku a další). Řízená krystalizace je složitějším procesem pro detailní nastavení procesních podmínek a jejich znalostí. Vede $\mathrm{k}$ produkci částic o požadované velikosti s dobrou reprodukovatelností procesu. Je nutno znát křivky rozpustnosti, šířku metastabilní oblasti, polymorfní chování dané látky, použít a volit vhodná rozpouštědla či aditiva. Nejčastěji využívaným principem je přidání krystalů do matečného roztoku (tzv. očkování) $)^{23}$. Obecně je při tvorbě inhaland klasická krystalizační metoda ve farmaceutické praxi využívaná jako počáteční krok pro získání krystalické účinné látky. Ta je většinou dále upravována jinými převážně mikronizačními metodami. Při pokusech o změnu tvaru částic laktosy pro výhodnější plicní depozici bylo zjištěno, že jehlicovité částice měly při dalším zpracování vhodnější vlastnosti než kvádrové ${ }^{14}$. Při zmenšování velikosti částice je nutno brát v potaz možnou fyzikálně-chemickou změnu produktu (povrchová energie, velikost distribuce částic, povrch, hustota, vznik el. náboje, zvýšení hygroskopicity, výskyt amorfních struktur atd.) $)^{23}$.

Sonokrystalizace umožňuje přípravu produktu o požadovaných vlastnostech pro plicní aplika$\mathrm{ci}^{24,25}$.Vlivem tzv. kavitačního efektu jsou ultrazvukem o frekvenci $20-100 \mathrm{~Hz}$ tvořeny $\mathrm{v}$ matečném roztoku mikrobubliny. Ty jsou místem, kde vznikají matečná jádra, což umožní uniformní růst částic. Ultrazvukem generovaná teplota a tlakový gradient mají vliv na výslednou morfologii a snižují agregaci vznikajících částic ${ }^{22}$. Sonokrystalizací lze formulovat např. antiastmatikum salbutamol. Muhammad a spol. připravili z roztoku salbutamol-fosfátu suchý krystalický prášek $\mathrm{s}$ krystaly délky $0,5-3,0 \mu \mathrm{m}$ o šírce $0,01-0,30 \mu \mathrm{m}$. Byl použit ultrazvuk o frekvenci $24 \mathrm{~Hz}$ a isopropanol jako antisolvent. Za použití sprejové sušárny byly zformované částice vysušeny ${ }^{26,27}$. Př́íkladem léčivého přípravku používaného $\mathrm{k}$ léčbě astmatu a CHOPN je pomocí sonokrystalizace vyráběný Seretide ${ }^{\circledR}$ (GlaxoSmithKline, Irsko) s obsahem bronchodilatans salmeterolxinafoátu $^{28}$.

Př́prava částic pomocí superkritické fluidní technologie je jednou $\mathrm{z}$ novějších krystalizačních metod $\mathrm{v}$ přípravě mikro- i nanočásticových systémů. Technologie využívá vlastností tzv. superkritických kapalin (nejčastěji oxid uhličitý nebo ethanol), které mají vlastnosti na hranici mezi plynem a kapalinou. Jde o látky vysoce stlačitelné s hustotou kapaliny a vysokou rozpouštěcí kapacitou i selektivitou ${ }^{29,30}$. Tuto metodu lze využít dvěma směry. V prvním př́padě je superkritická kapalina využita jako rozpouštědlo. Látka rozpuštěná $\mathrm{v}$ superkritické kapalině po dekompresi precipituje a je získán výsledný produkt. Zástupci této metody jsou REES a PGSS. REES je schopná produkovat částice $\mathrm{s}$ relativně úzkou velikostní distribucí. PGSS se používá nejčastěji u polymerních materiálů, kde je využito jejich plastifikace díky rozpustnosti v $\mathrm{SC}-\mathrm{CO}_{2}$. Druhý způsob využití SC je její použití jako antisolventu (snižuje rozpustnost účinné látky $\mathrm{v}$ primárním rozpouštědle). SC jako antisolvent probublává roztokem léčiva a díky nerozpustnosti účinné látky $v$ něm se tvoří částice. Produkované částice jsou obvykle nesférické a vykazují nízkou sypnou hustotu. Velký vliv na výsledný produkt má geometrie trysky. SEDS je modifikací PGSS metody, kde je použita multikomponentní tryska. Další novější technikou je tzv. ASES, kdy je roztok účinné látky rozprašován do prostředí superkritické kapaliny. SFEE se využívá $\mathrm{k}$ extrakci vnitřní fáze emulze olej ve vodě $(\mathrm{o} / \mathrm{v})$. Výsledné částice vykazují termodynamicky stabilní vlastnosti a jsou uniformni ${ }^{30-32}$. Kanlara a spol. s využitím SC formulovali porézní chitosanové částice $\mathrm{s}$ inkorporovanými nanočásticemi nesoucí GLP-1 a si-RNA pro léčbu diabetu. $\mathrm{V}$ prvním kroku byly připraveny nanočástice si-RNA o velikosti $100-150 \mathrm{~nm}$ enkapsulované do chitosanu metodou iontové gelace. Následně z takto připravených nanočástic vznikly pomocí $\mathrm{CO}_{2}$ jako antisolventu nano-mikro porézní částice. Jejich nosič byl tvořen PGLA a GLP-1 byl použit jako účinná látka. Střední velikost výsledných částic dosahovala 4,7 $\mu \mathrm{m}$. Inhalační podání laboratorním myším prokázalo prodloužený účinek snížení glykemie, způsobený synergickým vlivem GLP-1 a si-RNA (cit. ${ }^{33-35}$ ).

\subsection{Mikronizace a mletí}

Pro produkci částic s respirabilní velikostí se využívají dva typy mlýnů - kulové a fluidní. Princip nejčastěji používaného tryskového mlýnu (fluidní mletí) spočívá ve vzájemné kolizi částic unášených hnacích médiem při vysoké rychlosti. Vzniklé částice jsou turbulencí plynů odváděny $\mathrm{z}$ pracovní komory, větší setrvávají $\mathrm{k}$ další mikronizaci $^{30}$. Touto metodou mohou být produkovány částice o velikosti $1-20 \mu \mathrm{m}$. Důležitá je velikost $(75-1000 \mu \mathrm{m})$ a fyzikální vlastnosti vstupního materiálu (křehkost, plasticita atd.) $)^{3,36,37}$. Mletí v kulovém mlýnu je centrifugální nebo planetární pohyb mlecích koulí, které svým pohybem drtí materiál $\mathrm{v}$ prostoru mezi nimi ${ }^{37}$. Nevýhodou mlecích procesů je nedostatečná kontrola velikosti, morfologie a povrchových vlastností částic a vznik elektrostatického náboje, který snižuje aerosolizovatelnost vzniklého prášku. Mikronizací samotnou nelze docílit vzniku částic složitějších struktur (např. porézní, duté částice, nanočásticové struktury, částice s modifikovaným povrchem) $)^{36,37}$. Ganderton a spol. použitím tryskového mlýnu mikronizovali inzulinový prášek na inhalovatelnou velikost okolo $2,4 \mu \mathrm{m}$ $\left(\right.$ cit. $\left.^{34}\right)$. Zhang a spol. tryskovým mletím připravili sedmifragmentový úsek CSP, který má potenciál pro léčbu idiopatické cystické fibrózy. Výsledné částice o aerodynamickém průměru $1,58 \pm 0,1 \mu \mathrm{m}$ a FPF $93,3 \pm 3,3 \%$ byly inhalačně podány laboratorním myším. Účinek depozice byl potvrzen statisticky významným snížením kolagenní tkáně v postižených plicích ${ }^{35}$.

\subsection{Sprejové sušení}

Představuje jednoduchou a ekonomicky přijatelnou cestu př́pravy částic pro plicní podání. Principem je rozprášení kapalné disperze účinných a pomocných látek přes trysku a následné vysušení letících kapek odpařením rozpouštědla ${ }^{5,38,39}$. V prvním kroku dochází $\mathrm{k}$ atomizaci vstupní disperze přes trysku. Tento krok má výrazný vliv na parametry výsledného produktu. Záleží na rychlosti proudícího plynu, typu použitého atomizéru, koncentraci a viskozitě disperze a rychlosti postupu disperze směrem 
$\mathrm{k}$ atomizéru ${ }^{39}$. V dalším kroku dochází $\mathrm{v}$ temperované pracovní komoře $\mathrm{k}$ odpaření rozpouštědla $\mathrm{z}$ kapek vzniklých atomizací. Nejprve se odpařuje rozpouštědlo z povrchu, tím se zvyšuje koncentrace pevné složky na povrchu. Formuje se částice s kapalným jádrem. Následně se směrem dovnitř celá částice prohřívá, čímž je dosušeno zbylé množství rozpouštědla. Celý proces se odehrává za letu kapek sušící komorou ${ }^{5}$. Vzniklé částice putují přes separační zařízení (cyklona, filtr, elektrostatická separace) do sběrné nádoby ${ }^{39-41}$. Sprejové sušení se často kombinuje $\mathrm{s}$ jinými metodami, např́íklad enkapsulací. Vanbever a spol. připravili sprejovým sušením škálu suchých porézních práškových formulací z $\beta$-laktosy a albuminu s obsahem léčiv (albuterol, inzulin, $\beta$-estradiol) s geometrickým průměrem 3-15 $\mu \mathrm{m}$ a setřesnou hustotou $0,04-0,60 \mathrm{~g} \mathrm{~cm}^{-3}$. Průměrná hodnota aerodynamického průměru byla určena v rozmezí 1-3 $\mu \mathrm{m}$. Respirabilní frakce a emitovaná dávka byly určeny za použití Andersonova kaskádového impaktoru, kdy byl prášek aerosolizován $\mathrm{z}$ DPI Spinhaler ${ }^{\mathrm{TM}}$ (Aventis, France) $^{42}$.

\subsection{Sprejová lyofilizace}

Jedná se o proces, kdy je disperze s léčivem nastříknuta do pracovní komory, která je podchlazena kryogenní kapalinou, typicky kapalným dusíkem. Touto metodou lze připravit nano- a mikročástice k plicní aplikaci. Metoda je technologicky i finančně náročnější než klasické sprejové sušení. Využívá se převážně pro termolabilní látky určené $\mathrm{k}$ inhalaci ${ }^{43}$. V prvním kroku dochází k prudkému zmrazení nastř̌ikovaných kapek disperze ${ }^{22}$. Tento krok je určující z pohledu výsledné velikosti a tvaru částic. Následně dojde k lyofilizaci rozpouštědla. Výsledkem jsou obvykle sférické porézní částice s nízkou hustotou, vykazující lepší aerosolizační a tokové vlastnosti ${ }^{44}$. Ve studii Al-Hakima a spol. byla porovnána morfologie částic vzniklých sprejovým sušením a sprejovou lyofilizací. SD částice měly hladký povrch a vyšší hustotu oproti porézním částicím vzniklých SFD (cit. ${ }^{45}$ ). Přri provedení metody klasickým způsobem tzv. SFG dochází ke zmrazení kapek nad hladinou kapalného dusíku. Modifikovaná metoda SFL spočívá $\mathrm{v}$ nástřiku disperze prrímo do kryogenní kapaliny a vede ke vzniku jemnějších povrchových struktur a snížené agregaci částic. Yu a spol. prripravili SFL porézní inzulinové mikročástice o aerodynamickém průměru $5-7 \mu \mathrm{m}$ a nízké hustotě $0,002-0,015 \mathrm{~g} \mathrm{~cm}^{-3}$ ( cit. $^{46}$ ).

\subsection{Kombinované techniky (emulgace, enkapsulace)}

Pro tvorbu suchých práškových formulací jsou emulgační a enkapsulační techniky používány jako mezioperační postup. Částice se do pevné fáze převádí použitím další metody (sprejové sušení, lyofilizace, odpaření druhé fáze atd.). Velikost a uniformita vznikajících sférických částic hrají v inhalační terapii významnou roli (biodostupnost, cílená depozice, chemická a fyzikální stálost). Vhodná je např́klad metoda membránové emulzifikace. Kapalina je do jiné nemísitelné kapaliny extrudována přes membránu o definované velikosti pórů (př́má emulzifikace), nebo muže být vnitřní fáze částečně předemulgována (premixní metoda) $)^{47}$. Edwards a spol. použili emulgační metody $\mathrm{k}$ přípravě porézních a neporézních částic z PLGA a testosteronu. Neporézní částice (pozn. fyzická velikost $d_{\mathrm{geo}}=$ $\left.3,5 \mu \mathrm{m}, \rho=0,8 \mathrm{~g} \mathrm{~cm}^{-3}\right)$ vykazovaly výrazně nižší respirabilní frakce oproti částicím porézním $\left(d_{\text {geo }}=8,5 \mu \mathrm{m}, \rho=\right.$ $\left.0,1 \mathrm{~g} \mathrm{~cm}^{-3}\right)^{5}$. Enkapsulace resp. mikroenkapsulace přináší řadu výhod převážně pro léčiva, u nichž lze touto technikou zvýšit jejich stabilitu a účinek. Vhodným nosičem mohou být např. liposomy, které mají schopnost difundovat do mukózní vrstvy plic. Liposomy jsou aerosolizovány nebulizérem produkujícím homogenní velikost částic. Enkapsulaci je možné kombinovat $\mathrm{s}$ dalšími metodami za tvorby složitějších porézních částicových struktur sloužících jako nosič liposomálních resp. nanočásticových formulací $^{13}$. Př́íkladem liposomální formulace je Ambisome ${ }^{\circledR}$ (Astellas Pharma US Inc., USA). Jde o nebulizační přípravek obsahující antifungální makrolid amfotericin B používaný jako prevence aspergilosy u pacientů po transplantaci plic $^{48}$.

\section{Závěr}

Za optimální způsob dopravení léčiva do požadovaných částí plic lze v současnosti považovat aplikaci velkých porézních suchých částic sloužících jako nosiče účinných látek. Tyto částice se vyznačují lepšími aerodynamickými vlastnostmi umožňujícími hlubokou plicní depozici a delším setrváním v místě působení. V současnosti se dále rozvíjejí metody jejich př́pravy. Sprejové sušení patří k nejpoužívanějším metodám, a lze ho kombinovat s ostatními výrobními procesy (enkapsulace, emulgace, mikronizace atd.). Pro vyhodnocení aerodynamických vlastností částic jsou použíaány specifické metody jako hodnocení pomocí Andersonova kaskádového impaktoru, APS, atd. Pro simulaci co nejrealističtějších podmínek byl na VUT Brno vytvořen model umělých plic a simulátor dechového cyklu. Experimentem in vitro tak lze zjistit koncentraci aerosolu v konkrétní části plic za použití různých dechových módů (normální dýchání, astmatik, lobektomie atd.).

Práce vznikla za podpory projektu MUNI/1213/2020.

\section{Seznam zkratek}

$\begin{array}{ll}\text { APS } & \text { aerodynamic particle sizer } \\ \text { ASES } & \begin{array}{l}\text { aerosol solvent extraction system process } \\ \text { chronická obstrukční plicní nemoc }\end{array} \\ \text { CHOPN } & \begin{array}{l}\text { diferenční skenovací kalorimetrie } \\ \text { DSC }\end{array} \\ \text { cSP } & \text { caveolin scaffolding domain peptide } \\ \text { CT } & \text { počítačová tomografie } \\ \text { DCD } & \text { dolní cesty dýchací } \\ \text { DM II } & \text { diabetes mellitus druhého typu } \\ \text { DPI } & \text { dry powder inhaler } \\ \text { GLP-1 } & \text { glucagon like peptide 1 } \\ \text { LPP } & \text { large porous particles } \\ \text { MDI } & \text { metered dose inhaler }\end{array}$




$\begin{array}{ll}\text { MMAD } & \begin{array}{l}\text { mass median aerodynamic diameter } \\ \text { Magnetická rezonance }\end{array} \\ \text { PGSS } & \begin{array}{l}\text { particle from gas saturated solution process } \\ \text { kopolymer kyseliny polymléčné a lysinu } \\ \text { pLAL-Lys }\end{array} \\ \text { PLGA } & \begin{array}{l}\text { kyselinléčná-glykolová) kyselina } \\ \text { PLLA }\end{array} \\ \text { REES } & \text { rapid expansion of supercritical solutions } \\ \text { SC } & \text { supercritical } \\ \text { SC-CO } & \text { supercritical carbon dioxide } \\ \text { SEDS } & \text { solution enhanced dispersion by supercritical } \\ & \text { fluid } \\ \text { SF } & \text { superkritická kapalina } \\ \text { SFEE } & \text { supercritical fluid extraction from emulsion } \\ \text { SFG } & \text { spray freezing into gas } \\ \text { SFL } & \text { spray freezing into liquids } \\ \text { SFV } & \text { spray freezing into vapour } \\ \text { si-RNA } & \text { small interfering ribonucleic acid } \\ \text { STK } & \text { Stokesovo číslo } \\ \text { VUT } & \text { Vysoké učení technické } \\ \text { XRD } & \text { rentgenová prášková difrakce }\end{array}$

\section{LITERATURA}

1. Cryan S. A., Sivadas N., Garacia-Contreras L.: Adv. Drug Delivery Rev. 60, 858 (2008).

2. Musante C. J., Schroeter J. D., Rosati J. A., Crowder T. M., Hickey A. J., Martonen T. B.: J. Pharm. Sci. 91, 1590 (2002).

3. Rasenack N., Steckel H., Müller B. W. J.: Pharm. Sci. 92, 35 (2003).

4. Kašáková E., Kašák V.: Prakt. Lékáren. 11, 16 (2015).

5. Edwards D. A., Hanes J., Caponetti G., Hrkach J., Ben-Jebria A., Eskew M. L., Mintzes J., Deaver D., Lotan N., Langer R.: 276, 1868 (1997).

6. Lízal F.: Experimentální výzkum transportu a depozice aerosolů $v$ dýchacím traktu člověka. Disertačni práce. Vysoké učení technické v Brně, Brno 2012.

7. Yeh H.-CH., Cuddihy R. G., Phalen R. F., Chang I.-Y.: Aerosol Sci. Technol 25, 134 (1996).

8. Chan H. K.: Colloids Surf., A 284, 50 (2006).

9. Heyder J., Gebhart J., Rudolf G., Schiller C. F., Stahlhofen W.: J. Aerosol Sci. 17, 811 (1986).

10. Weers J. G., Miller D. P.: J. Pharm. Sci. 104, 3259 (2015).

11. Iskandar F., Nandiyantc A. B. D., Widiyastuti W., Young L. S., Okuyama K., Grandon L.: Acta Biomaterialia 5, 1027 (2009).

12. Ministerstvo zdravotnictví ČR: Český lékopis 2009. Grada, Praha 2009.

13. Wagner A., Vorauer- Uhl K., Katinger H.: J. Liposome Res. 16, 113 (2006).

14. Kamin W. E. S., Genz T., Roeder S., Scheuch G., Trammer T., Juenemann R., Cloes R. M.: J. Aerosol Med. 15, 65 (2002).

15. Rubin B. K., Fink J. B.: Respir. Care 50, 1191 (2005).

16. Hinds W. C.: Aerosol Technology: Properties, Behavior, and Measurement of Airborne Particles. John Wiley \& Sons, New Jersey 1999.

17. Hořavová H., Gajdziok J., Vetchý D.: Chem. Listy
114, 322 (2020).

18. Vanbever R., Mintzes J. D., Wang J., Nice J., Chen D., Batycky R., Langer R., Edwards D. A.: Pharm. Res. 16, 1735 (1999).

19. Farkas A., Lízal F., Jedelský J., Elcner J., Karas J., Bělka M., Mišik O., Jicha M.: J. Aerosol Sci. 147, 105582 (2020).

20. Bělka M.: In vitro výzkum vlivu vlastností částic a prìtoku vzduchu na regionální depozici $v$ dýchacích cestách člověka. Disertační práce. Vysoké učení technické v Brně, Brno 2018.

21. Bělka M., Lízal F., Jedelský J., Elcner J., Hopke K.P., Jicha M.: J. Aerosol Sci. 117, 149 (2018).

22. Grandon L., Sosnowski T. R.: Adv. Powder Technol. 25, 43 (2014).

23. Moura C., Neves F., Costa E.: Powder Technol. 298, 90 (2016).

24. Luque De Castro M. D., Priego-Capote F.: Ultrason. Sonochem. 14, 717 (2007).

25. Dhumal R. S., Biradar S. V., Paradkar A. R., York P.: Int. J. Pharm. 368, 129 (2009).

26. Muhammad S. A. F. S., Oubani H., Abbas A., Chan H.-K., Kwok P. C. L., Dehghani F.: Powder Technol. 246, 337 (2013).

27. Abbas A., Srour M., Tang P., Chiou H., Chan H.-K., Romagnoli J. A.: Chem. Eng. Sci. 62, 2445 (2007).

28. Kratochvíl B.: Chem. Listy 101, 3 (2007).

29. Kou X., Chan L.,W., Steckel H., Heng P. W. S.: Adv. Drug Delivery Rev. 64, 220 (2012).

30. Shoyele S. A., Cawthorne S.: Adv. Drug Delivery Rev. 58, 1009 (2006).

31. Školáková T., Zámostný P.: Chem. Listy 114, 591 (2020).

32. Gombotz W. R., Healy M. S., Brown L. R., Auer H. E.: US 6569458B1.

33. Kankala R. K., Lin X.-F., Tang N., Xu P.-Y., Hao L.-Z., Yang D.-Y., Wang S.-B., Zhang Y.-S., Chen A.-Z.: ACS Biomater. Sci. Eng. 8, 4225 (2018).

34. Ganderton D., Kassem N. M.: US 5254330.

35. Zhang Y., MacKenzie B.-A., Koleng J. J., Maier E., Warnken Z. N., Williams R. O.: Mol. Pharmaceutics 17, $632(2020)$.

36. Johnson K. A.: Adv. Drug Delivery Rev. 26, 3 (1997).

37. Picler G., Amighi K.: Int. J. Pharm. X 396, 1 (2010).

38. Haque M. A., Timilsena Y. P., Adhikari B., v knize: Drying Technologies for Foods: Fundamentals \& Applications (Nema P. K., Kaur B. P., Mujumdar A. S., ed.) kap. 4, str. 79. Taylor \& Francis, New Dehli 2015.

39. Cal K., Sollohub K.: J. Pharm. Sci. 99, 575 (2010).

40. Vicente J., Pinto J., Menezes J. C., Gaspar F.: Powder Technol. 247, 1 (2013).

41. Souchová P.: Příprava sprejově sušené laktosy z vodných roztoků o vysoké koncentraci. Diplomová práce. Univerzita Karlova, Hradec Králové, 2019.

42. Vanbever R., Mintzes J. D., Wang J., Nice J., Chen D., Batycky R., Langer R., Edwards D. A.: Pharm. Res. 16, 1735 (1999).

43. Okamoto H., Sakakura Y., Shiraki K., Oka K., 
Nishida S., Todo H., Iida K., Danjo.: Int. J. Pharm. 290, 73 (2005).

44. Gac J. M., Grandoń L.: Adv. Powder Technol. 24, 324 (2013).

45. Al-Hakim K., Stapley A. G. F., ve sborníku: 14th international drying symposium, 22-25 August, Sao Paulo, Brazílie, str. 120, Madera 2004.

46. Yu Z., Rogers T. R., Hu J., Johnston K. P., Williams R. O.: Eur. J. Pharm. Biopharm. 54, 221 (2002).

47. Willis L., Hayes D., Mansour H. M.: Lung 190, 251 (2012)

J. Karas, D. Vetchý, and J. Gajdziok (Department of Pharmaceutical Technology, Faculty of Pharmacy, Masaryk University, Brno): Dry Powder Particles for Pulmonary Application

The deposition of a drug to its required destination is crucial for effective lung treatment. It is important to design a suitable formulation that delivers the active ingredient to the desired site and resists the natural cleansing mechanisms of the airways. Large porous particles used as active substance carriers appear to be the most effective option for lung drug delivery. The present article provides a basic overview of the mechanisms of deposition of dry inhalable powders and methods of their preparation and evaluation. Spray drying together with micronization and crystallization techniques are among the most used methods of preparation of the discussed particles. Besides, these techniques can be combined with other production processes (encapsulation, emulsification, etc.). The evaluation of the properties of particles suitable for pulmonary application is based on specific requirements for their density, porosity, shape, aerodynamic parameters, and deposition in the lungs, which can now be simulated on an accurate model of artificial lungs.

Keywords: dry powder inhalation, large porous particles, particles preparation methods, spray drying, lung particle deposition, artificial lungs

- Karas J., Vetchý D., Gajdziok J.: Chem. Listy 116, 28-34 (2022).

- https://doi.org/10.54779/chl20220028

Acknowledgements

This work was supported by grant project MUNI/1213/2020. 